\title{
Oral manifestations of primary hyperoxaluria in adult patient
}

\author{
Manifestação oral da hiperoxalúria primária em paciente adulto \\ Manifestaciones orales de la hiperoxaluria primaria en paciente adulta
}

Received: 04/24/2021 | Reviewed: 05/03/2021 | Accept: 05/07/2021 | Published: 05/21/2021

\author{
Marina Sena Lopes da Silva Sacchetto \\ ORCID: https://orcid.org/0000-0002-8433-941X \\ Clinical Hospital of Federal University of Minas Gerais, Brazil \\ E-mail: marinaslopes@yahoo.com.br \\ Maísa Pereira da Silva \\ ORCID: https://orcid.org/0000-0003-2483-8695 \\ Clinical Hospital of Federal University of Minas Gerais, Brazil \\ E-mail: maisaodonto1@gmail.com \\ Roberta da Silva D'AlessandroTonello \\ ORCID: https://orcid.org/0000-0002-0193-7781 \\ Clinical Hospital of Federal University of Minas Gerais, Brazil \\ E-mail: Roberta.tonello@ebserh.gov.br \\ Wagner Henriques de Castro \\ ORCID: https://orcid.org/0000-0003-2745-2878 \\ Clinical Hospital of Federal University of Minas Gerais, Brazil \\ E-mail: wagnerhcastro@hotmail.com
}

\begin{abstract}
Primary hyperoxaluria $(\mathrm{PH})$ is a rare disease, autosomal recessive inheritance disorder. This disease leads to overproduction of oxalates, and the excretation inability results in deposition of calcium oxalate crystals in almost all tissues presenting the oxalosis condition. The treatment is a combined liver and kidney transplantation (CLKT), which enables a better patient survival. Due to this survival, the patients had could present a several oral manifestations such as periodontal disease, root resorption, dental pain and increased tooth mobility. However, currently, there is a lack of information in the literature about all oral manifestations that this patient can present. Beside this, there are doubt and challenge about treatments to this patient in these different oral manifestations. The present study aims to report a case of a patient with hyperoxaluria type I with oxalosis oral manifestations.
\end{abstract}

Keywords: Hyperoxaluria; Oxalates; Transplants; Therapeutics.

\section{Resumo}

A hiperoxalúria primária (HP) é uma doença rara de herança autossômica recessiva. Essa doença leva à superprodução de oxalatos, e a incapacidade de excreção resulta na deposição de cristais de oxalato de cálcio em quase todos os tecidos que apresentam a condição de oxalose. $\mathrm{O}$ tratamento é o transplante combinado de fígado e rim (TCFR), que permite melhor sobrevida do paciente. Devido a esta sobrevida os pacientes puderam apresentar diversas manifestações bucais como doença periodontal, reabsorção radicular, dor dentária e aumento da mobilidade dentária. Porém, até o momento, faltam informações na literatura sobre todas as manifestações orais que esse paciente pode apresentar. Ao lado disso temos uma dúvida e um desafio quanto aos tratamentos a esse paciente nessas diferentes manifestações orais. O presente trabalho tem como objetivo relatar um caso de uma paciente com hiperoxalúria tipo I, apresentando manifestações orais de oxalose.

Palavras-chave: Hiperoxalúria; Oxalatos; Transplantes; Terapêutica.

\section{Resumen}

La hiperoxaluria primaria (HP) es una enfermedad rara, un trastorno hereditario autosómico recesivo. Esta enfermedad conduce a la sobreproducción de oxalatos y la incapacidad de excreción da como resultado el depósito de cristales de oxalato de calcio en casi todos los tejidos que presentan la condición de oxalosis. El tratamiento es un trasplante combinado de hígado y riñón (TCHR), que permite una mejor supervivencia del paciente. Debido a esta supervivencia los pacientes pudieron presentar diversas manifestaciones bucales como enfermedad periodontal, reabsorción radicular, dolor dentario y aumento de la movilidad dentaria. Sin embargo, hasta la fecha, existe una falta de información en la literatura sobre todas las manifestaciones bucales que puede presentar este paciente. Además de esto, tengo una duda y un desafío sobre los tratamientos a este paciente en estas diferentes manifestaciones orales. El presente estudio tiene como objetivo reportar el caso de un paciente con hiperoxaluria tipo I con manifestaciones orales de oxalosis.

Palabras clave: Hiperoxaluria; Oxalatos; Transplantes; Terapéutica. 


\section{Introduction}

Primary hyperoxaluria (PH) is a rare inherited autosomal recessive disorder (Guerra et al. 2014; Siegal et al. 2011; Pijnenburg. et al. 2017; Cochat\&Rumsby, 2013). The affected genes are involved in glyoxylate metabolism (Guerra et al. 2014), and its deficiency leads to overproduction of oxalates (Pijnenburg. et al. 2017; Cochat\&Rumsby, 2013). Kidney's inability to excrete oxalates results in the deposition of these calcium oxalate crystal in almost all tissues (oxalosis) and the failure of multiple organs. (Benmoussa et al. 2015)

Hyperoxaluria type I (PHI) is the most common (70-80\%) and is caused by intrahepatic deficiency of alanine glyoxylate aminotransferase (AGT)(Guerra et al. 2014; Siegal et al. 2011; Pijnenburg. et al. 2017; Cochat\&Rumsby, 2013), which leads to overproduction of oxalate, and affects 1 to 3 cases per million individuals. Hyperoxaluria type II (PH2) has an oxalate overproduction caused by deficiency in glyoxylate reductase-hydroxypyruvate reductase (GRHPR) (Guerra et al. 2014; Pijnenburg. et al. 2017; Cochat\&Rumsby, 2013) corresponding to 10\% of Hiperoxaluria cases. Hyperoxaluria type III (PH3) is caused by failure in enzyme 4-hydroxy-2-oxoglutaratealdolase (HOGA) (Pijnenburg. et al. 2017; Cochat\&Rumsby, 2013). Calcium oxalate is highly insoluble salt that is an end-product, and is excreted almost entirely by kidney, but can crystallize in the renal tubules. The first symptoms are urolithiasis, and nephrocalcinosis, which lead to a progressive kidney involvement and chronic kidney disease (Cochat\&Rumsby, 2013). The hemodialysis does not provide sufficient oxalate elimination, and patients may need liver and kidney transplants to correct metabolic abnormalities (Siegal et al. 2011).

Several oral findings have been described in patients with oxalosis, such as periodontal disease, root resorption (Benmoussa et al. 2015; Rinksma et al. 2008), dental pain and increased tooth mobility (Rinskma et al. 2008). Bone and dental resorption may be the result of chronic inflammation and the presence of osteoclastic cells surrounding the deposited calcium oxalate crystal (Guerra et al. 2014). This deposition can result in aggressive tooth resorption and alveolar bone loss, which can be misdiagnosed as periodontal disease. Oxalosis should be considered in the diagnosis of bone loss associated with external root resorption (Guerra et al. 2014; Rinksma et al. 2008).

Oxalosis treatment with combined liver and kidney transplantation (CLKT) enables a better patient survival, which has caused an increase in the number of patients with oral hyperoxaluria lesions (Benmoussa et al. 2015; Rinksma et al. 2008). These patients need to be followed to diagnose these earlier manifestations and be encouraged to maintain good oral health to prevent periodontal diseases (Benmoussa et al. 2015). Therefore, due to its rarity and impact on oral health, the present study aims to report a case of a patient with hyperoxaluria type I, with emphasis on the oral manifestations.

\section{Methodology}

The present paper consists of a case report of a patient evaluated in Clinical Hospital of Federal University of Minas Gerais (HC/UFMG/EBSERH in Portuguese), with hyperoxaluria type I, which present new oral manifestations of oxalosis. This study applied the methodology as described in Pereira (2018), and the Informed Consent Form fulfilled by the patient during clinical attendance.

\section{Case Report}

During routine evaluation on an intensive care unit, oral manifestations were observed on a 25-year-old female patient diagnosed with chronic kidney disease, stage 5 (CKD V), secondary to oxalosis. According to the hospital records, the patient has been followed up at hospital since the eighth month of life with renal disease when she started renal replacement therapy, being submitted to peritoneal dialysis. During treatment, there were three kidney transplants and a successful hepatic transplant. Patient remains on renal support therapy in hemodialysis three times per week. 
During this study, the patient presented pulmonary, cardiovascular, bone, respiratory and endocrine-metabolic complications, and required the use of Bilevel Positive Pressure Airway (BIPAP). Eventually, she needed hospitalization in ICU for treatment of acute complications. Due to the patient's severe systemic condition, and the impossibility of having a new kidney transplant, her treatment is based on stability and comfort. During hospitalization, was performed a routine dental evaluation, which detected retained deciduous tooth, tooth loss associated with bone exposures in anterior region mandible and maxilla and irregular alveolar ridge, with an increase in volume in the anterior region of the mandible (Figure 1).

Figure 1. Clinical signs: A. Bone exposures in anterior region of maxilla, and absence of teeth. B. Bone exposures, irregular alveolar ridge, with an increase in volume in the anterior region of the mandible.

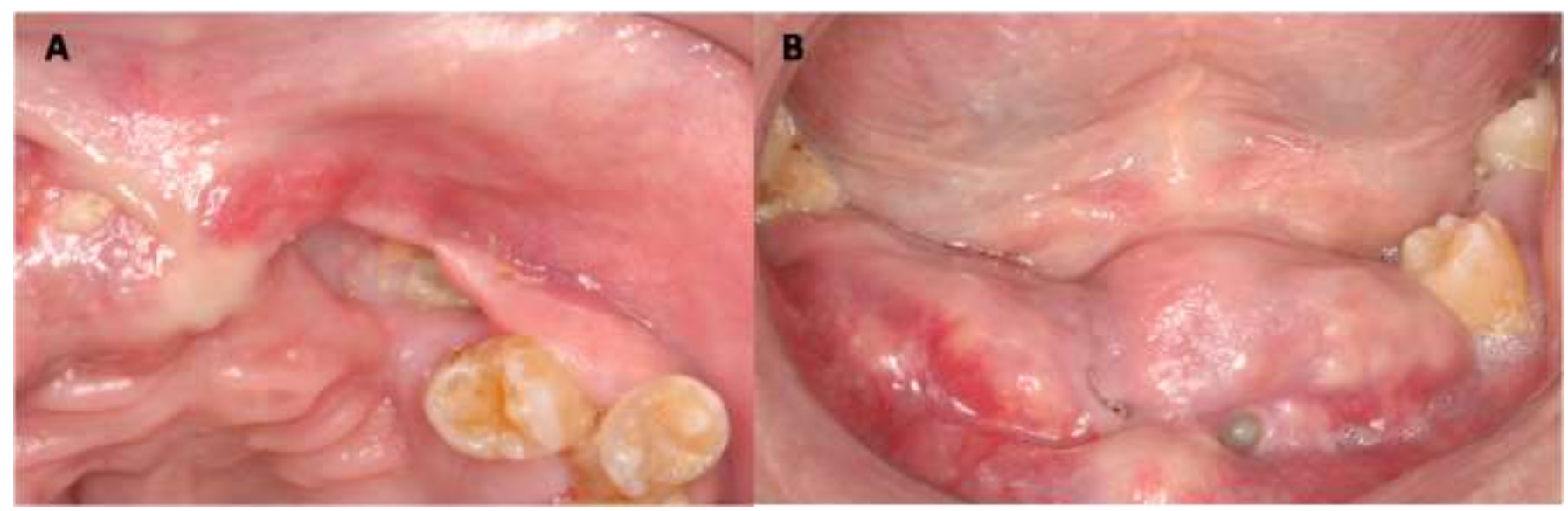

Source: Own authorship.

Computed tomography (CT) confirmed the presence of retained teeth, which was associated with an increase in volume in the anterior region of the mandible. The region of clinical bone exposure coincides with the region of the tomography, where there is an absence of soft tissue in axial sections. In this region, it is possible to notice dental elements (Figure 2). In the images can also be observed a change in bone density, both in the mandible and maxilla. 
Figure 2. Imaging Exam: A. Panoramic by computed tomography that can see a presence of retained teeth, and irregular alveolar ridge. Presence of oxalate in bone structure. B. Three-dimensional (3D) reconstruction image.

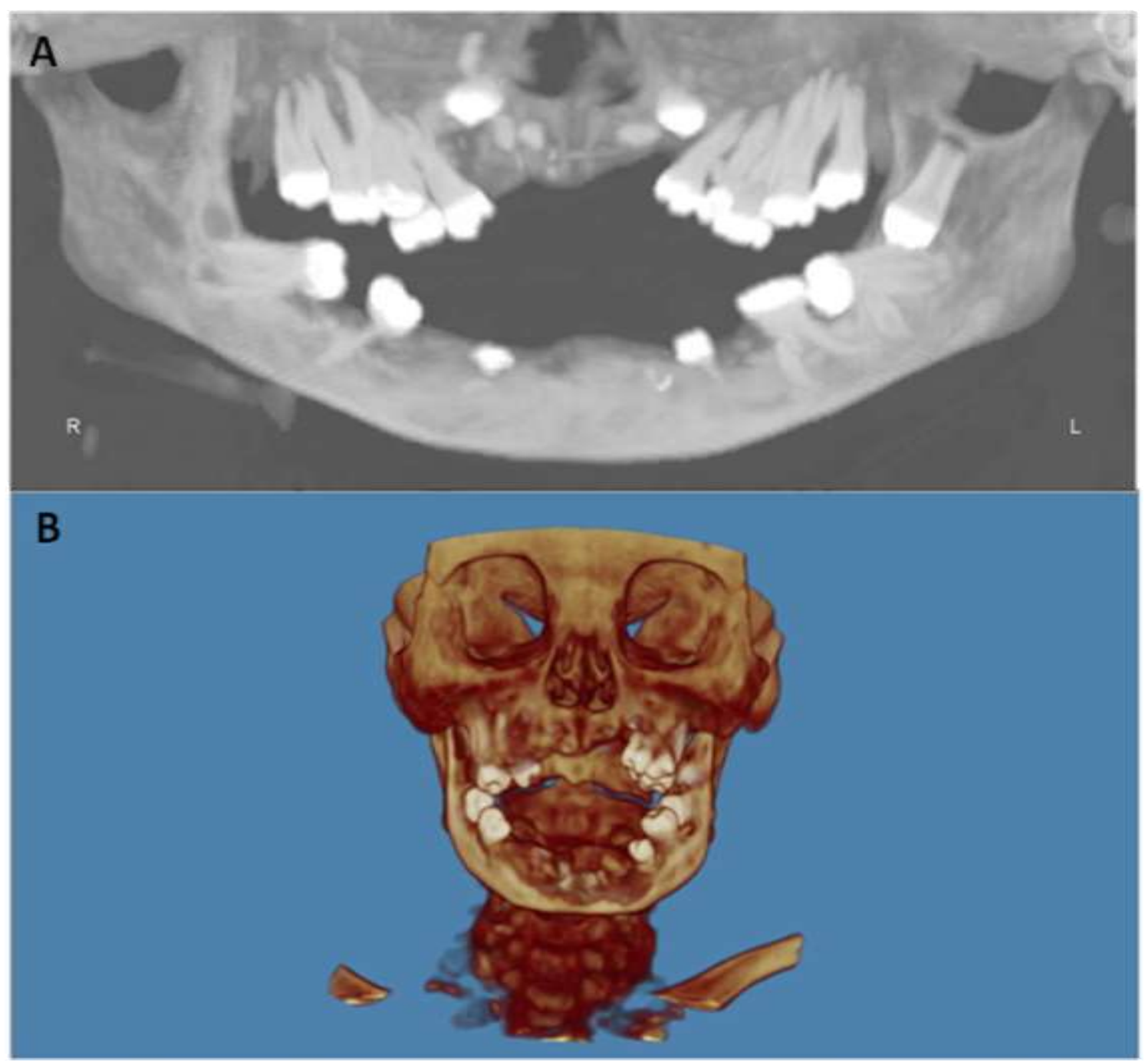

Source: Own authorship.

Dental approach was discussed with the medical team, and, as consensus, we decided to perform the follow up and, in case of pain or infection, invasive procedures would be performed. In view of this guidance, the dentistry team opted for periodic follow-up to assess areas of bone exposure and early diagnosis of possible infections. The patient's family was trained in oral hygiene, with irrigation of bone exposures with $0.12 \%$ chlorhexidine. The need for regular tooth brushing was also emphasized to prevent gingivitis and periodontitis, common conditions and patients with chronic kidney disease.

\section{Discussion}

Primary hyperoxaluria can occur at any age, until sixth decade of life, with an average age of 5.5 years. (Cochat \& Rumsby, 2013; Lieske et al. 2005) Renal disorder is the main manifestation that can lead to diagnosis, even so $10 \%$ of patients will only be diagnosed when the disease recurs after kidney transplantation. ${ }^{4}$ In literature, has been reported a good survival rate of these patients after CLKT. (Jamieson, 2005; Cibrik et al. 2002) However, oral manifestations of hyperoxaluria after treatment has been scarce in the literature. (Benmoussa et al. 2015) In 1982, Wysocki et al., at the beginning of hemodialysis, reported extrarenal signs and symptoms, due to the survival rate of these patients and the systemic manifestations of disease. The CLKT allows the increase of survival rate and this leads to new manifestations, including oral manifestations. These oral 
manifestations, previously absent, nowadays require a more careful evaluation by specialists for the early diagnosis and treatment of these patients. These signs were observed in our case report, in which the patient underwent three transplants, and the oral manifestations were diagnosed in 2020, seven years after the last kidney transplantation. Although there was no previous record of dental changes, the patient's parents report having noticed changes in the oral cavity, but did not have access to a dental professional. This highlights the importance of regular dentistry follow-up for patients with complex chronic diseases.

Periodontal disease was one of the first manifestations observed (Panis et al. 2010), however, other signs and symptoms may occur, such as bone resorption, external root resorption, tooth mobility, dental pain associated with oxalate deposition in the dentin and pulp (Mitsimponas et al. 2012), as well as dental retention. In radiographic findings of these patients, we can observe radiolucent lesions and changes in bone matrix mineralization, due to a defect in bone formation, as well as increased bone resorption, such as changes in the number or activity of the osteoblast. (Selvi et al. 2009; Kalyvas et al. 2004) The condition of chronic kidney disease itself can lead to bone abnormalities. (Proctor et al. 2005) However, it is important to differentiate the condition of hyperoxaluria from bone pathologies such as brown tumors. These patients may present with hyperparathyroidism leading to great osteoclastic activity, however radiologically brown tumors are radiolucent, intraosseous and well-defined, with alteration of the cortical bone. (Wysocki et al. 1982; Selvi et al. 2009)

In the present case, patient had an early diagnosis of oxalosis after the second kidney transplant, and could then be submitted to other transplants, as well as liver transplantation. However, the absence of dental care hampered by the patient's systemic condition, led to early tooth loss. Owing to the permeability and deposition of oxalate crystals in the periodontium, they are detected as foreign bodies and cause an inflammatory reaction leading to the destruction of the tissue (Panis et al. 2010; Fantasia et al. 1982; Chen et al. 2001; Popa-Nita \& Naccache, 2010) and its replacement by non-calcified tissue leading to mobility. (Boyce et al. 1986) The injury of the periodontium by oxalate has been widely discussed in the literature, as well as its deposition in bone tissue or soft tissue. (Moskow, 1989) The present case presented an early tooth loss, impaction of some teeth, and bone exposure. Despite the wide discussion of the pathology, we observed an absence in the literature regarding the healing process of these tissues, as well as the occurrence of this exposure.

\section{Final Considerations}

The novelty of the oral conditions that these patients may present, as the increase in survival leads us to determine specific protocols and care for these patients, making early dental care very important. Care must be initiated from the diagnosis of the disease, due to the oral impairment that oxalose can cause. Periodic follow-up, associated with periodontal care, as well as radiographic exams are important for conducting treatment. Bone exposure, something not previously reported in the literature, must be closely monitored to not be an infection port of entry, since surgical procedures, ambulatory or hospital are at greater risk for this patient. This fact can be observed in the case described, in which the medical team instructed to carry out only extremely necessary procedures aimed at resolving the patient's complaints, with an emphasis on comfort. The case reported presented the importance of a multidisciplinary approach in patients with HP. The dental surgeon is essential to identify oral manifestations that can interfere with the patient's approach. These manifestations can inclusive help in earlier diagnosis of this rare disease.

\section{References}

Benmoussa, L., Renoux, M., \& Radoï, L. (2015). Oral Manifestations of Chronic Renal Failure Complicating a Systemic Genetic Disease: Diagnostic Dilemma. Case Report and Literature Review. Journal of oral and maxillofacial surgery : official journal of the American Association of Oral and Maxillofacial Surgeons, 73(11), 2142-2148. https://doi.org/10.1016/j.joms.2015.05.029. 
Boyce, B. F., Prime, S. S., Halls, D., Johnston, E., Critchlow, H., MacDonald, D. G., \& Junor, B. J. (1986). Does osteomalacia contribute to development of oral complications of oxalosis?. Oral surgery, oral medicine, and oral pathology, 61(3), 272-277. https://doi.org/10.1016/0030-4220(86)90374-9.

Chen, W. C., Wu, H. C., Chen, H. Y., Wu, M. C., Hsu, C. D., \& Tsai, F. J. (2001). Interleukin-1beta gene and receptor antagonist gene polymorphisms in patients with calcium oxalate stones. Urological research, 29(5), 321-324. https://doi.org/10.1007/s002400100193.

Cibrik, D. M., Kaplan, B., Arndorfer, J. A., \& Meier-Kriesche, H. U. (2002). Renal allograft survival in patients with oxalosis. Transplantation, 74(5), 707710. https://doi.org/10.1097/00007890-200209150-00020.

Cochat, P., \& Rumsby, G. (2013). Primary hyperoxaluria. The New England journal of medicine, 369(7), 649-658. https://doi.org/10.1056/NEJMra1301564

Fantasia, J. E., Miller, A. S., Chen, S. Y., \& Foster, W. B. (1982). Calcium oxalate deposition in the periodontium secondary to chronic renal failure. Oral surgery, oral medicine, and oral pathology, 53(3), 273-279. https://doi.org/10.1016/0030-4220(82)90303-6.

Guerra, E. N., Vianna, L., Sobreira, M. N., de Araújo, F. N., \& de Melo, N. S. (2011). Oral manifestations of hyperoxaluria. The Journal of craniofacial surgery, 22(6), 2191-2192. https://doi.org/10.1097/SCS.0b013e3182324130

Jamieson, N. V., \& European PHI Transplantation Study Group (2005). A 20-year experience of combined liver/kidney transplantation for primary hyperoxaluria (PH1): the European PH1 transplant registry experience 1984-2004. American journal of nephrology, 25(3), 282-289. https://doi.org/10.1159/000086359.

Kalyvas, D., Tosios, K. I., Leventis, M. D., Tsiklakis, K., \& Angelopoulos, A. P. (2004). Localized jaw enlargement in renal osteodystrophy: report of a case and review of the literature. Oral surgery, oral medicine, oral pathology, oral radiology, and endodontics, 97(1), 68-74. https://doi.org/10.1016/s10792104(03)00381-0.

Lieske, J. C., Monico, C. G., Holmes, W. S., Bergstralh, E. J., Slezak, J. M., Rohlinger, A. L., Olson, J. B., \& Milliner, D. S. (2005). International registry for primary hyperoxaluria. American journal of nephrology, 25(3), 290-296. https://doi.org/10.1159/000086360

Mitsimponas, K. T., Wehrhan, T., Falk, S., Wehrhan, F., Neukam, F. W., \& Schlegel, K. A. (2012). Oral findings associated with primary hyperoxaluria type I. Journal of cranio-maxillo-facial surgery : official publication of the European Association for Cranio-Maxillo-Facial Surgery, 40(8), e301-e306. https://doi.org/10.1016/j.jcms.2012.01.009.

Moskow B. S. (1989). Periodontal manifestations of hyperoxaluria and oxalosis. Journal of periodontology, 60(5), 271-278. https://doi.org/10.1902/jop.1989.60.5.271

Panis, V., Tosios, K. I., Gagari, E., Griffin, T. J., \& Damoulis, P. D. (2010). Severe periodontitis in a patient with hyperoxaluria and oxalosis: a case report and review of the literature. Journal of periodontology, 81(10), 1497-1504. https://doi.org/10.1902/jop.2010.100092.

Pereira, A. S., Shitsuka, D. M., Parreira, F. J. \& Shitsuka, R. (2018). Metodologia da pesquisa científica. UFSM.

Pijnenburg, L., Caillard, S., Boivin, G., Rizzo, S., \& Javier, R. M. (2018). Type 1 primary hyperoxaluria: A case report and focus on bone impairment of systemic oxalosis. Morphologie : bulletin de l'Association des anatomistes, 102(336), 48-53. https://doi.org/10.1016/j.morpho.2017.09.004

Popa-Nita, O., \& Naccache, P. H. (2010). Crystal-induced neutrophil activation. Immunology and cell biology, 88(1), 32-40. https://doi.org/10.1038/icb.2009.98

Proctor, R., Kumar, N., Stein, A., Moles, D., \& Porter, S. (2005). Oral and dental aspects of chronic renal failure. Journal of dental research, 84(3), 199-208. https://doi.org/10.1177/154405910508400301.

Rinksma, A. J., Oosterhuis, J. W., Wolvius, E. B., \& van der Wal, K. G. (2008). Oral manifestations of oxalosis: a case report and review of the literature. Journal of oral and maxillofacial surgery : official journal of the American Association of Oral and Maxillofacial Surgeons, 66(9), 1953-1956. https://doi.org/10.1016/j.joms.2007.09.018.

Selvi, F., Cakarer, S., Tanakol, R., Guler, S. D., \& Keskin, C. (2009). Brown tumour of the maxilla and mandible: a rare complication of tertiary hyperparathyroidism. Dento maxillo facial radiology, 38(1), 53-58. https://doi.org/10.1259/dmfr/81694583

Siegal, D., Su, W. S., DaBreo, D., Puglia, M., Gregor, L., \& Gangji, A. S. (2011). Liver-kidney transplantation in primary hyperoxaluria type-1: case report and literature review. International journal of organ transplantation medicine, 2(3), 126-132.

Wysocki, G. P., Fay, W. P., Ulrichsen, R. F., \& Ulan, R. A. (1982). Oral findings in primary hyperoxaluria and oxalosis. Oral surgery, oral medicine, and oral pathology, 53(3), 267-272. https://doi.org/10.1016/0030-4220(82)90302-4. 